\title{
Hexanal Vapor Induced Resistance against Major Postharvest Pathogens of Banana (Musa acuminata L.)
}

\author{
Durgadevi Dhakshinamoorthy ${ }^{1 \dagger}$, Srivignesh Sundaresan ${ }^{1+\pi}$, Arumukapravin Iyadurai ${ }^{1}$, Kizhaeral Sevathapandian \\ Subramanian (1) ${ }^{1 *}$, Gnanaguru Janaki Janavi ${ }^{1}$, Gopinathan Paliyath ${ }^{2}$, and Jayasankar Subramanian ${ }^{2}$ \\ ${ }^{1}$ Department of Nano Science \& Technology, Tamil Nadu Agricultural University, Coimbatore 641003, India \\ ${ }^{2}$ Plant Agriculture, University of Guelph, Guelph, ON LOR 2EO, Canada \\ ${ }^{\top}$ Current address: Department of Horticulture and Floriculture, Central University of Tamil Nadu, Thiruvarur 610005, \\ India
}

(Received on March 28, 2019; Revised on October 10, 2019; Accepted on December 3, 2019)

Hexanal, a C-6 aldehyde has been implicated to have antimicrobial properties. Hence, this study was conducted to determine the antifungal activities of hexanal vapor against major postharvest pathogens of banana viz., Colletotrichum gloeosporioides and Lasiodiplodia theobromae. The pathogens were cultured in vitro and exposed to hexanal vapor at 600, 800, 1,000 and 1,200 ppm. Mycelial growth of both fungal pathogens were inhibited completely at $800 \mathrm{ppm}$ and the incidence of anthracnose and stem-end rot diseases reduced by $75.2 \%$ and $80.2 \%$, respectively. The activities of peroxidase, polyphenol oxidase, phenylalanine ammonia-lyase and glucanase had transiently increased in hexanal vapor treated banana by 5 to 7 days and declined thereafter. Postharvest treatment of banana with hexanal vapor resulted in phospholipase $D$ inhibition and also resulted in cell wall thickening of the treated fruit, which impeded the penetration of the pathogenic spores. This was further confirmed by scanning electron micrographs. The defense-related protein intermediaries had increased in hexanal vapor treated

\footnotetext{
These authors contributed equally to this work.

*Corresponding author.

Phone) +91-422-6611527, FAX) +91-422-6611442

E-mail)kssubra2001@rediffmail.com,drres@tnau.ac.in

ORCID

Kizhaeral Sevathapandian Subramanian

https://orcid.org/0000-0001-6347-5546

(cc) This is an Open Access article distributed under the terms of the Creative Commons Attribution Non-Commercial License (http:// creativecommons.org/licenses/by-nc/4.0) which permits unrestricted noncommercial use, distribution, and reproduction in any medium, provided the original work is properly cited.
}

Articles can be freely viewed online at www.ppjonline.org. banana fruit, which suggests induced resistance against C. gloeosporioides and $L$. theobromae, via., the phenylpropanoid pathway which plays a significant role in hindering the pathogen quiescence. Delayed ripening due to inhibition of phospholipase $D$ enzyme, inhibition of mycelial growth and induced systemic resistance by defense enzymes collectively contributed to the postharvest disease reduction and extended shelf life of fruit.

Keywords : banana, defense proteins, hexanal, induced resistance, postharvest diseases

Handling Editor : Yong Hoon Lee

Banana (Musa acuminata L.), is a popular fruit and rich in nutrients, especially potassium (Kanazawa and Sakakibara, 2000). India is the largest producer of banana (30 million tonnes), holding $26.2 \%$ of the global share, with an export gross value of 3.48 billion USD (Ministry of Agriculture and Farmers' Welfare, 2018). Nearly, 20-25\% of fruits are lost due to poor postharvest management practices during various stages of the supply chain (Ministry of Agriculture, 2015). Such huge postharvest losses widen the gap between per-capita availability and supply which is estimated as nearly $50 \%$. Ripening of banana is accompanied by a wide array of physiological and biochemical changes (Alkarkhi et al., 2011; Mohapatra et al., 2010). Being a climacteric fruit, it continues ethylene evolution, postharvest which makes the fruit deteriorate rapidly (Boudhrioua et al., 2003). Fungal pathogenic diseases in banana account for the major cause of postharvest spoilage at all stages of supply chain until consumption (Kasso and Bekele, 2018). Forty-two different genera of fungi are known to attack ba- 
nana fruit during postharvest handling (Johnston and Jones, 1997). Anthracnose and stem-end rot caused by Colletotrichum musae and Lasiodiplodia theobromae, respectively are the most important fungal diseases affecting banana fruit (Abayasekara et al., 2013). These are opportunistic postharvest pathogens originating from quiescent infection and once established, the diseases are very difficult to manage.

The postharvest diseases are being managed through the application of fungicides as a dip or spray after harvest (Khan et al., 2001). Many fungicides are non-selective, leaving a considerable residue that affects the quality of fruit (López-Fernández et al., 2012). Hence, there is strong resistance from consumers who are alarmed by such residues, and its associated ill-effects on humans. Consequently, postharvest disease management has become quite challenging and there is increased need to find an alternate strategy to reduce the incidence of diseases using safe compounds that do not cause any health, safety or environmental issues.

Volatile compounds (organic and inorganic) are the products of secondary metabolism which can evaporate and disperse very rapidly into natural habitats and act as efficient chemical mediators. Many plant-based volatile organic compounds play a key role in the plant to plant communication (Baldwin et al., 2006), plant-insect and other defense interactions (Dobson, 2006; Heil and Silva Bueno, 2007). Similarly, bacterial volatile compounds have a broad impact on various organisms including plants, fungi, animals and bacteria (Sharifi and Ryu, 2018) acting as signaling compounds (Bailly et al., 2014), and plant defense elicitors (Ryu et al., 2004). Some of these volatile compounds act against postharvest pathogens and thereby the shelf life of fruit gets extended. There are several vapor treatments viz., 1-MCP, acetaldehyde, acetic acid, $\mathrm{CO}_{2}$ and hexanal that are used to delay the ripening of fruits (Baez-Sañudo et al., 2009; Fan et al., 2006; Gill et al., 2015; Myung et al., 2007; Song et al., 2007; Utto et al., 2008). The extension of shelf life of fruit is primarily attributed to the effective management of postharvest pathogens (Seethapathy et al., 2016; Sholberg, 2009).

Hexanal is a plant-derived biomolecule known to inhibit the phospholipase D (PLD) enzyme (lipoxygenase pathway) (Tiwari and Paliyath, 2011), and thus slow down the membrane deterioration (Paliyath and Droillard, 1992; Yuan et al., 2005) in fruits. Hexanal is categorized under generally recognized as safe and approved as a food additive by the U.S. food and drug administration, moreover, it is commercially available (Thavong et al., 2011). Hexanal formulations have been used as a preharvest spray
(Anusuya et al., 2016; El-Kayal et al., 2017a; Kumar et al., 2018; Sharma et al., 2010), postharvest dip (El Kayal et al., 2017b; Jincy et al., 2017) and vapor (Sholberg and Randall, 2007) to extend shelf life of tropical and temperate fruits. Among the modes of delivery hexanal vapor treatment is a very simple, economically feasible and socially practicable method to extend the shelf life of fruits. Hexanal inhibits postharvest pathogens such as Botrytis cinerea and Penicillium expansum (Sholberg and Randall, 2005; Song et al., 2010; Thavong et al., 2011). In addition, it has been shown that the exposure of hexanal vapor enhances the volatile and aroma compounds of apple (Lanciotti et al., 2003; Song et al., 1996). Earlier, we have shown that hexanal formulation had no deterrence against honey bees and natural enemies in sprayed mango orchards (Mohan et al., 2017). Despite the fact that the effectiveness of hexanal vapor on spore germination and mycelial growth of fungal pathogens for postharvest diseases have been studied in temperate fruits, the work on tropical fruit like banana is less investigated.

The present study hypothesized that hexanal vapor inhibits the pathogenicity by triggering plant defense enzymes and thus provides resistance against postharvest pathogens. To address this hypothesis, the current work was undertaken with three specific objectives namely, (1) to assess the pathogenicity of Colletotrichum gloeosporioides and Lasiodiplodia theobromae after exposure to hexanal vapor, (2) to gain insights into mechanisms involved in induced resistance (antioxidant enzyme activities and PLD) and (3) to study the shelf life of banana fruit after exposing to hexanal.

\section{Materials and Methods}

Cultures and virulence. Two fungi, $C$. gloeosporioides and $L$. theobromae, were isolated from infected banana fruit exhibiting typical anthracnose and stem-end rot symptoms, respectively. Primary confirmations of pathogens were mainly based on morphological characters and further confirmed through PCR with internal transcribed spacer primers (Sangeetha et al., 2012). The pathogens were isolated by the tissue segment method on potato dextrose agar (PDA) medium (Rangaswami and Mahadevan, 1999). The infected banana fruit tissue portions were cut into small pieces of $1.0 \mathrm{~cm}^{2}$, surface sterilized with $0.1 \%$ mercuric chloride for $30 \mathrm{~s}$, subsequently washed with sterile distilled water three times and dried over blotting paper. The surface-sterilized banana tissue segments were then placed on Petri plates containing $20 \mathrm{ml}$ of PDA medium and incubated at room temperature $\left(25 \pm 2^{\circ} \mathrm{C}\right)$ for further fungal 
growth. The cultures were purified by a single hyphal tip technique and maintained on PDA slants at $4^{\circ} \mathrm{C}$.

Hexanal vapor treatment. A plexiglass acrylic chamber measuring $45 \mathrm{~cm}$ length, $30 \mathrm{~cm}$ height, and $20 \mathrm{~cm}$ wide with a total volume of 271 was designed to study the vapor treatment. The concentration of hexanal vapor was calculated by considering the chamber volume and liquid to gas conversion ratio based on Avogadro's law (standard temperature and pressure, $273.15 \mathrm{~K}$ and $101.325 \mathrm{kPa}$, respectively). Thus to obtain various concentrations viz., $600,800,1,000$, and $1,200 \mathrm{ppm}$ of hexanal vapor, the volumes of hexanal liquid ( $98 \%$ purity, $0.8 \mathrm{~g} / \mathrm{ml}$ density at $25^{\circ} \mathrm{C}$; Sigma-Aldrich, St. Louis, MO, USA) required will be $101,136,170$, and $204 \mu 1$, respectively. The required concentrations of hexanal liquid were taken up in Petri dish and placed inside the top phase of the chamber, which was laid out with a slot to stand.

Impact of hexanal vapor on fungal mycelial growth (in vitro). The mycelial discs (5 $\mathrm{mm}$ diameter) of each fungal pathogen were taken from the periphery of an actively growing culture and placed at the center of a $90-\mathrm{mm}$ Petri dish containing PDA medium and then placed on the bottom portion of the acrylic chambers. Various concentrations of hexanal as described earlier (to give 600-1,200 ppm) was pipetted out in Petri plates and placed inside the acrylic chamber (Fig. 1). The Petri plates containing fungal mycelium were exposed to each concentration at different time intervals $(1,2,3$, and $4 \mathrm{~h})$ in different acrylic chambers. The control treatment had sterile water instead of hexanal vapor. The acrylic chamber was sealed with parafilm and placed at $25^{\circ} \mathrm{C}$, with three replicates for each volume and each fungal species. After the completion of pre-defined exposure hours, the Petri plates were removed, sealed and incubated at $25^{\circ} \mathrm{C}$ for further growth. After exposure to pre-defined time intervals the Petri plates were removed from the chamber, sealed and placed at $25^{\circ} \mathrm{C}$. The colony diameter was measured daily until the control plates attained $90 \mathrm{~mm}$ diameter (full length). The inhibitory effect

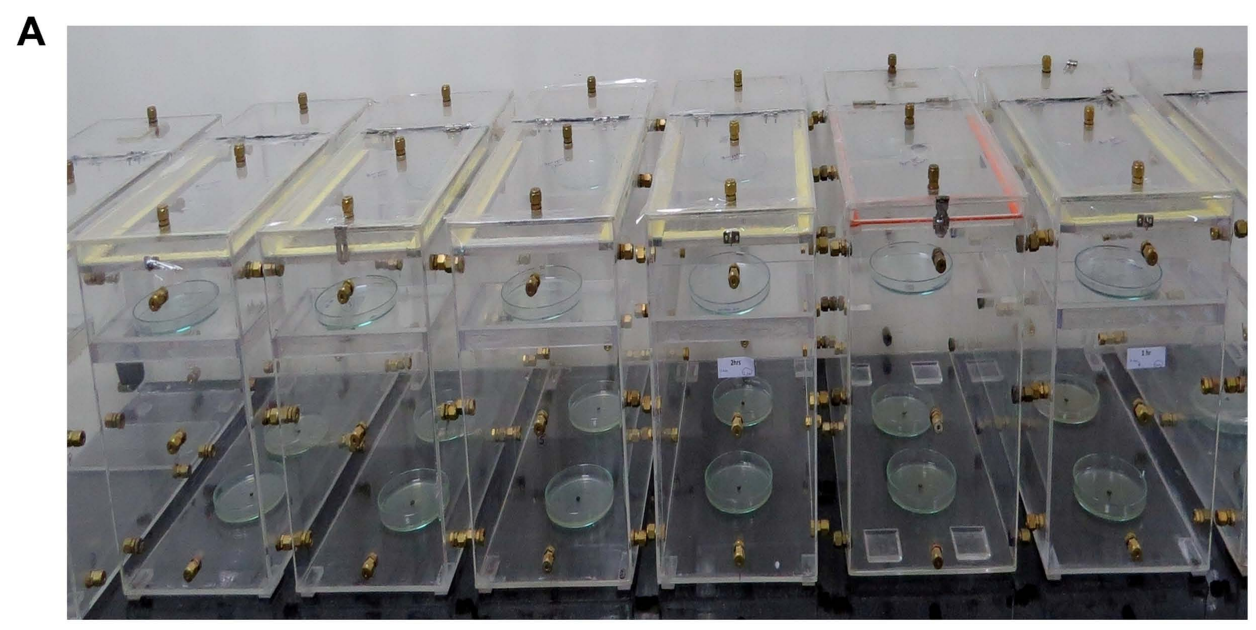

Overview of experimental setup

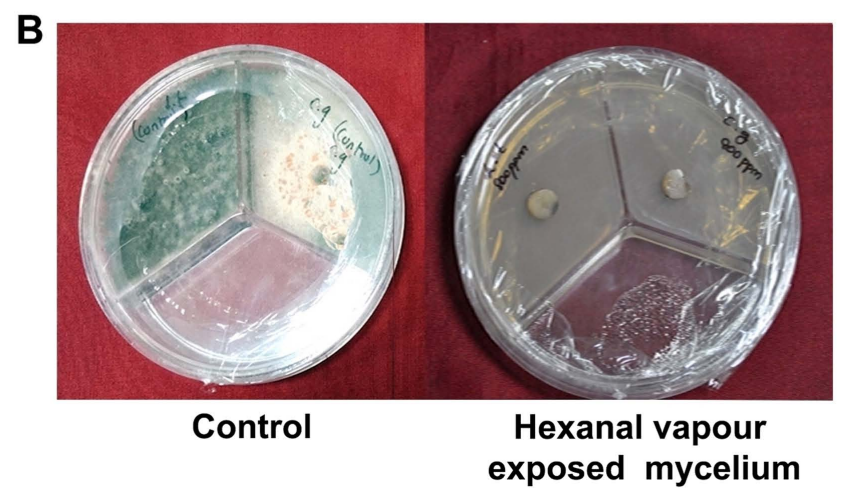

Fig. 1. In vitro screening of hexanal vapor against postharvest pathogens of banana. (A) Postharvest fungal pathogens exposed to hexanal vapor. (B) Tripartite plates inoculated with fungal pathogen and hexanal. The images were recorded seven days after inoculation. 
of each vapor treatment on mycelial growth was calculated as percent inhibition over the control.

Spore germination of $C$. gloeosporioides and $L$. theobromae (in vitro). The effects of hexanal vapor on spore germination and germ tube elongation of $C$. gloeosporioides and $L$. theobromae were assayed according to Liu et al. (2009). Aliquots $(50 \mu \mathrm{l})$ of both conidial suspensions at $2 \times 10^{6}$ spores $/ \mathrm{ml}$ were plated on tripartite Petri dishes (90 $\mathrm{mm}$ diameter) with PDA medium containing different volumes of hexanal $(0.36,0.48,0.60$, and $0.72 \mu \mathrm{l})$ and all Petri dishes were incubated at $25^{\circ} \mathrm{C}$. The respective controls were inoculated with sterile water instead of hexanal. Approximately, 10 spores of each pathogen were measured for germination rate within each replicate and the inhibition rate of spore germination was determined. Each treatment was replicated three times and the experiment was repeated twice.

Effect of hexanal vapor on banana diseases (in vivo). Anthracnose and stem-end rot suppression efficacies of hexanal vapor treatment on banana fruit were also evaluated. The banana var. Grand Naine was randomly handharvested at $85 \%$ maturity from the university orchard, Tamil Nadu Agricultural University, Coimbatore $\left(11.0^{\circ} \mathrm{N}\right.$ latitude and 76.9E longitude), Tamil Nadu, India. Banana fruits with uniform size and maturity were collected and surface sterilized with sodium hypochlorite $(1 \%)$ solution for $10 \mathrm{~min}$. The pathogenic spores $\left(5 \times 10^{5}\right.$ cells $)$ of $L$. theobromae and C. gloeosporioides were standardized using hemocytometer and $20 \mu \mathrm{l}$ of the suspension was placed in the middle of the fruit after a small pinprick (Fig. 2). Then, the fruit was exposed to various concentrations (600$1,200 \mathrm{ppm}$ ) of hexanal solution placed in the top phase of the acrylic chamber and exposed to $1,2,3$, and $4 \mathrm{~h}$. Then the fruits were transferred to clean box and observed for disease symptoms at ambient temperature. The disease severity (Percent Disease Index [PDI]) was determined for both diseases on the 14th day of treatment. The experiment was replicated three times. For each experiment, we used one hand of banana fruits with six to seven fingers of the same maturity, weighing $\sim 1.0 \mathrm{~kg}$.

The treated and untreated fruit tissues were cut and fixed in $2.5 \%$ glutaraldehyde solution for $2-3 \mathrm{~h}$. The fixed samples were then washed with an increasing concentration (step by step) of ethanol (0-100\%) and dried. Post-fixation was done with $1 \%$ osmium tetraoxide according to Wang et al. (2008). The resulting samples were documented using scanning electron microscopy (SEM). The PDI was calculated based on Prabakar et al. (2005) with slight modifica-
A

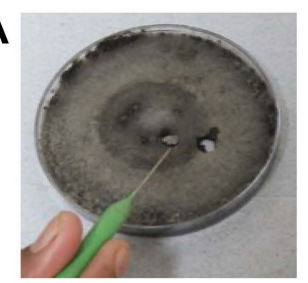

L. theobromae

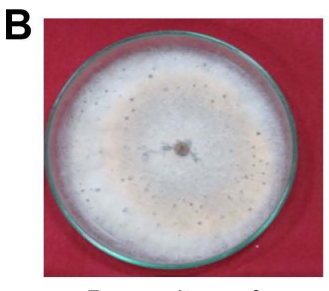

Pure culture of C. gloeosporioides
Pure culture of

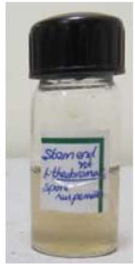

Spore suspension

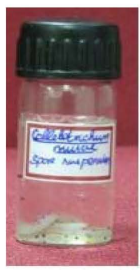

Spore suspension

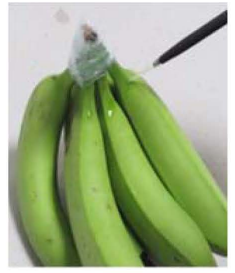

Spore suspension inoculated

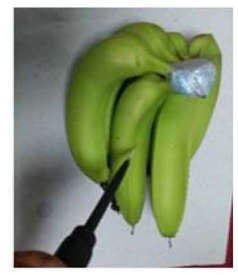

Spore suspension inoculated

\section{C}

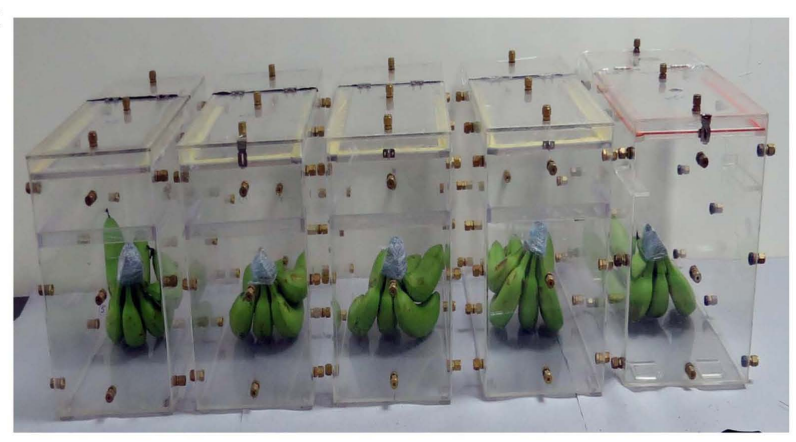

Banana fruits exposed to hexanal vapour (800 ppm)

Fig. 2. Inoculation of spore suspension in banana fruits by pinprick method with respective pathogens Lasiodiplodia theobromae (A), Colletotrichum gloeosporioides (B), banana var. Grand Naine fruits (C) exposed to hexanal vapor ( 800 ppm) after the inoculation of pathogens with respective controls inside the acrylic chamber.

tion, where scale 0 , no lesion development; scale 1, 1-25\% fruit surface area covered with lesions; scale 2, 26-50\% fruit surface area covered with lesions; scale 3, 51-75\% fruit surface area covered with lesions; scale $4,>75 \%$ fruit surface area covered with lesions.

$$
\begin{aligned}
& \begin{array}{l}
\text { Percent disease index }(\mathrm{PDI})= \\
\frac{\text { Sum of all numerical ratings }}{\text { Total no of fruits graded }}
\end{array} \frac{100}{\text { Max. disease grade }}
\end{aligned}
$$

Enzyme assays. Fruit samples were taken from the hexanal treated and control fruit with an interval of $1,3,6,9$, and 12 days after treatment. Exo- and endocarp tissue samples were collected, frozen in liquid nitrogen and stored at $-80^{\circ} \mathrm{C}$. Peroxidase (PO) activity (EC 1.11.1.7) was carried out as per the procedure described by Hammerschmidt et 
al. (1982) with slight modification in the reaction mixture total volume, where we used $2.5 \mathrm{ml}$ instead of $2.9 \mathrm{ml}$.

For phenylalanine ammonia-lyase (PAL) activity, one gram of banana fruit samples was homogenized with $3 \mathrm{ml}$ of ice-cold $0.1 \mathrm{M}$ sodium borate buffer, $\mathrm{pH} 7.0$, containing $1.4 \mathrm{mM}$ of 2-mercaptoethanol and $50 \mathrm{mg}$ of insoluble polyvinylpyrrolidone. The resulting extract was filtered and the filtrate was centrifuged at $20,000 \times g$ for $15 \mathrm{~min}$ at $4^{\circ} \mathrm{C}$ and the supernatant was used as the enzyme source. PAL activity (EC 4.3.1.5) was determined as the rate of conversion of L-phenylalanine to trans-cinnamic acid at $290 \mathrm{~nm}$. Sample containing $0.4 \mathrm{ml}$ of enzyme extract was incubated with $0.5 \mathrm{ml}$ of $0.1 \mathrm{M}$ borate buffer, $\mathrm{pH} 8.8$ and $0.5 \mathrm{ml}$ of $12 \mathrm{mM}$ L-phenylalanine in the same buffer for $30 \mathrm{~min}$ at $30^{\circ} \mathrm{C}$. The amount of trans-cinnamic acid synthesized was calculated using its extinction coefficient of $9,630 / \mathrm{M} / \mathrm{cm}$ (Dickerson et al., 1984). Enzyme activity was expressed in fresh weight basis as nmol trans-cinnamic acid/min/mg of plant tissue.

For glucanase (EC 3.2.1.39) activity, $1 \mathrm{~g}$ tissue of banana peel and pulp were homogenized in $5 \mathrm{ml}$ of $0.05 \mathrm{M}$ sodium acetate buffer ( $\mathrm{pH}$ 5.0) and the homogenate was centrifuged at $20,000 \times \mathrm{g}$ for $10 \mathrm{~min}$ at $4^{\circ} \mathrm{C}$ and the supernatant was used as enzyme source. $\beta$-1,3-glucanase activity was assayed by the laminarin-dinitrosalicylic acid method (Pan et al., 1991). The reaction mixture consisted of $62.5 \mu \mathrm{l}$ of $4 \%$ laminarin (Sigma-Aldrich) and $62.5 \mu 1$ of enzyme extract. The reaction was carried out at $40^{\circ} \mathrm{C}$ for $10 \mathrm{~min}$. The reaction was stopped by adding $375 \mu \mathrm{l}$ of dinitrosalicylic acid and heated for $5 \mathrm{~min}$ in boiling water, vortexed and its absorbance was measured spectrophotometrically at $500 \mathrm{~nm}$ (SPECORD 210 PLUS, Konrad-Zuse-Str-Jena, Germany). The enzyme activity was expressed as $\mu \mathrm{g}$ glucose released/ $\mathrm{min} / \mathrm{mg}$ of the sample.

Phenolic compounds were assayed as per the method of Liu et al. (2008) with some modifications. The samples ( 0.5 g) were homogenized with $5 \mathrm{ml}$ ice-cold $1 \% \mathrm{HCl}$-methanol solution and then centrifuged at $12,000 \times \mathrm{g}$ for $10 \mathrm{~min}$ at $4^{\circ} \mathrm{C}$. The supernatant was removed, absorbance measured at 280 and $325 \mathrm{~nm}$ in a spectrophotometer (SPECORD 210 PLUS). Gallic acid was used as a standard.

Determination of PLD activity. The fresh tissues of banana were ground using $0.2 \mathrm{M}$ phosphate buffer ( $\mathrm{pH}$ 7.0) and the PLD enzyme activity was quantified using PLD assay kit (EC 3.1.4.4., Sigma-Aldrich) following the procedure described in Jincy et al. (2017).

Evaluation of hexanal vapor on the pathogenesis of fruit peel and pulp. To determine the effects of hexanal treatment on fruit peel and pulp morphology, as well as the effect of pathogen inoculation, samples were collected on the 6th day after treatment (color break stage in control fruits). The peel and pulp samples were collected from the middle portion of the fruit and immediately dipped $-20^{\circ} \mathrm{C}$ ethanol for $3 \mathrm{~s}$ and stored at $-80^{\circ} \mathrm{C}$ until further analysis. At the time of analysis, the sample was affixed to a carbon stub and vacuum desiccated for 2 min to remove excess moisture. The peel and pulp samples were examined using a scanning electron microscope (Quanta 250, FEI, Hillsboro, OR, USA) with an Everhart-Thornley Detector detector. The SEM was operated in a vacuum, $10 \mathrm{kV}$, with a spot size of 3.5 and a pressure of $60 \mathrm{~Pa}$. The images were recorded at $500 \times$ and $1,000 \times$ magnifications.

Shelf-life studies. Fruit samples were drawn once in three days from control and treated, till the fruit get completely spoilt to assess the shelf life using physiological, biochemical and quality parameters as repeated earlier (Anusuya et al., 2016).

Statistical analysis. The data were statistically analyzed using the IRRISTAT version 92 (International Rice Research Institute Biometrics unit, Manila, Philippines) developed by the International Rice Research Institute Biometrics unit, the Philippines. Prior to statistical analysis of variance (ANOVA), the percentage values of the disease index were arcsine transformed. Data were subjected to ANOVA at two significant levels $(P<0.05$ and $P<0.01)$ and means were compared by Duncan's multiple range test (Supplementary Tables 1-8).

\section{Results}

Hexanal vapor treatment on mycelial growth and spore viability. The pathogens exposed to varying concentrations of hexanal vapor (600 to $1,200 \mathrm{ppm}$ ) under in vitro conditions and the maximum mycelial growth in control plates were attained after 7 days of inoculation. Exposure to hexanal at 1,000 or 1,200 ppm for one hour resulted in the complete inhibition of mycelial growth in both. At a lower concentration of hexanal, such as $800 \mathrm{ppm}$ it required longer exposure time ( $3 \mathrm{~h}$ ) to achieve complete inhibition (Fig. 3 ). Spore viability of $C$. gloeosporioides and $L$. theobromae decreased with increasing concentrations and duration of exposure to hexanal. At $800 \mathrm{ppm}$ (and higher) of hexanal vapor, spore viability decreased rapidly and germination was totally inhibited after an hour of exposure (Fig. 4). Hence 800 ppm was used in commercial fruit packaging studies/assay due to complete inhibitory effect at low con- 

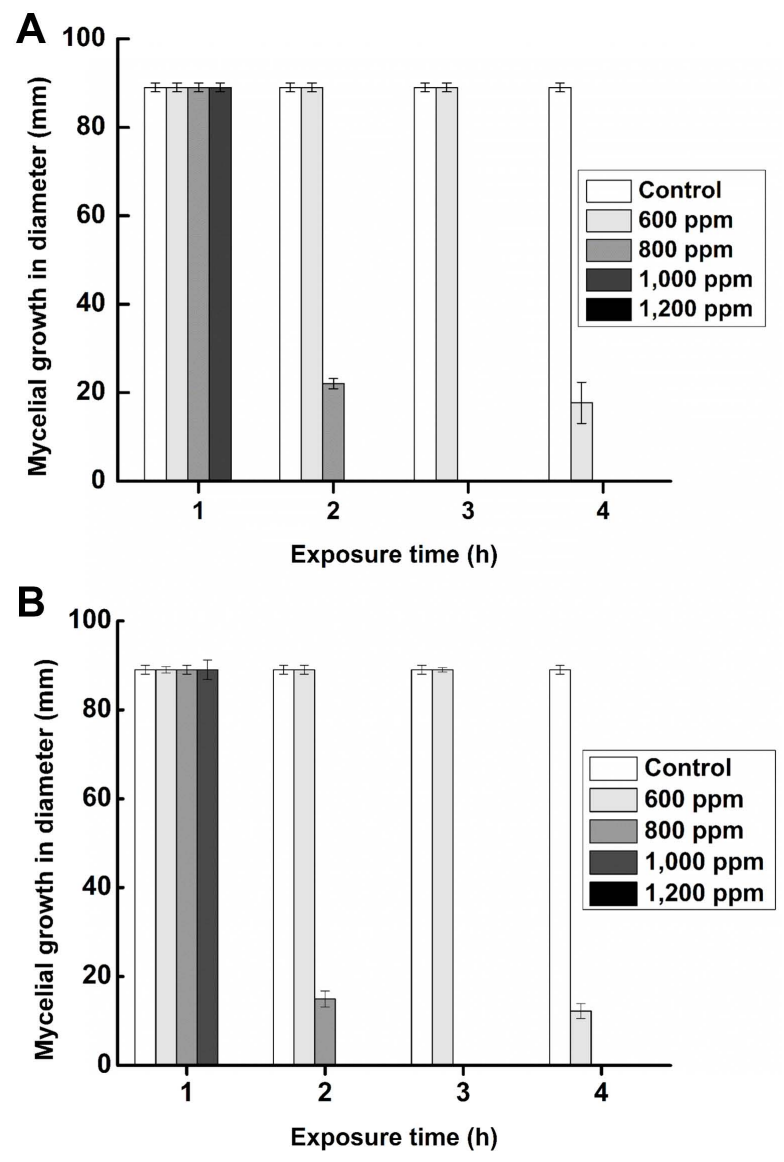

Fig. 3. In vitro screening of hexanal vapor exposure; Lasiodiplodia theobromae (A), Colletotrichum gloeosporioides (B) mycelial growth on potato dextrose agar medium after 7 days. The fungal mycelium was exposed to hexanal vapor at various concentrations $600,800,1,000$, and 1,200 ppm with different exposure times $(0-4 \mathrm{~h})$. The data represent the means of 3-4 replicates \pm SE.

centrations as well as the economic benefit gained through minimal usage of a volatile compound.

Effect of hexanal vapor on lesion development and shelf life. In general fruits stayed without any noticeable lesion for 6 days and thereafter lesions were more prominent. Fruits that were exposed to $800 \mathrm{ppm}$ for $3 \mathrm{~h} \mathrm{had}$ registered the lowest incidence of stem-end rot (1.61\%) and anthracnose $(1.12 \%)$ on 15th day of observation. On the other hand, infection started becoming visible on 6th day in control fruits and progressed steadily thereafter. On the 15th day incidence of stem-end rot and anthracnose reached $78.5 \%$ and $88.2 \%$ respectively and the fruits were lost for any practical purposes (Figs. 5 and 6). Correspondingly, the treated fruits stayed well until 14 days, fit for marketing/consumption. Hexanal vapor exposed fruit had
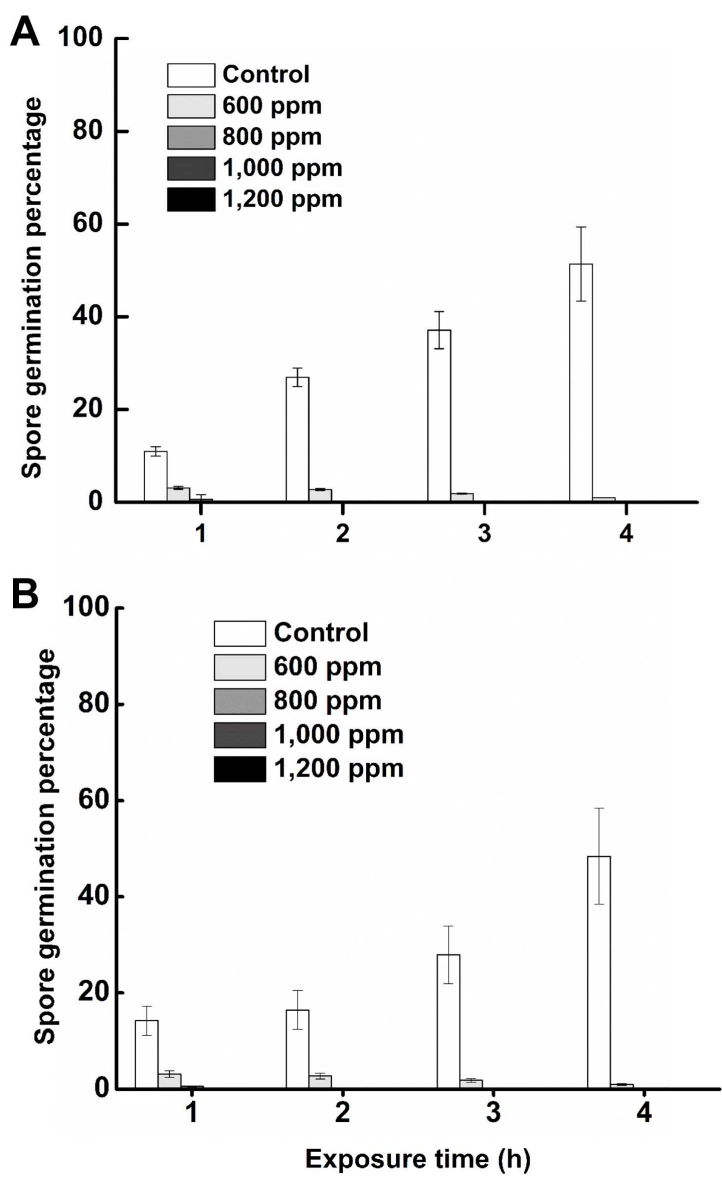

Fig. 4. Effect of hexanal vapor on spore germination of Lasiodiplodia theobromae (A) and Colletotrichum gloeosporioides (B) pathogens. The data represent the means of 3-4 replicates \pm SE.

the smallest lesion size of 0.3 and $0.5 \mathrm{~cm}$ for stem-end rot and anthracnose, respectively at 15 th day. The corresponding lesion sizes measured in control fruit were 3.7 and 7.5 $\mathrm{cm}$ (Fig. 7). We observed the disease incidence in healthy control even after surface sterilization (Fig. 5), appears to be a normal case in banana fruits. This might be due to the endemic as a latent form of pathogen propagules which is carried from green fruit and expressed symptoms during ripening. Our scoring (PDI formulae) was based only on true disease symptoms rather than normal discoloration.

Changes in the PO, PAL, and glucanase activities in banana fruit. The PO activity had transiently increased till seven days and declined thereafter regardless of treatment. Hexanal treatment (800 ppm) and pre-inoculation with both pathogens (C. gloeosporioides, L. theobromae) had significantly higher PO activities (1.314 and 1.312 changes in absorbance $/ \mathrm{min} / \mathrm{g}$ of fresh tissue, respectively) than control ( 0.414 changes in absorbance $/ \mathrm{min} / \mathrm{g}$ of fresh 
A

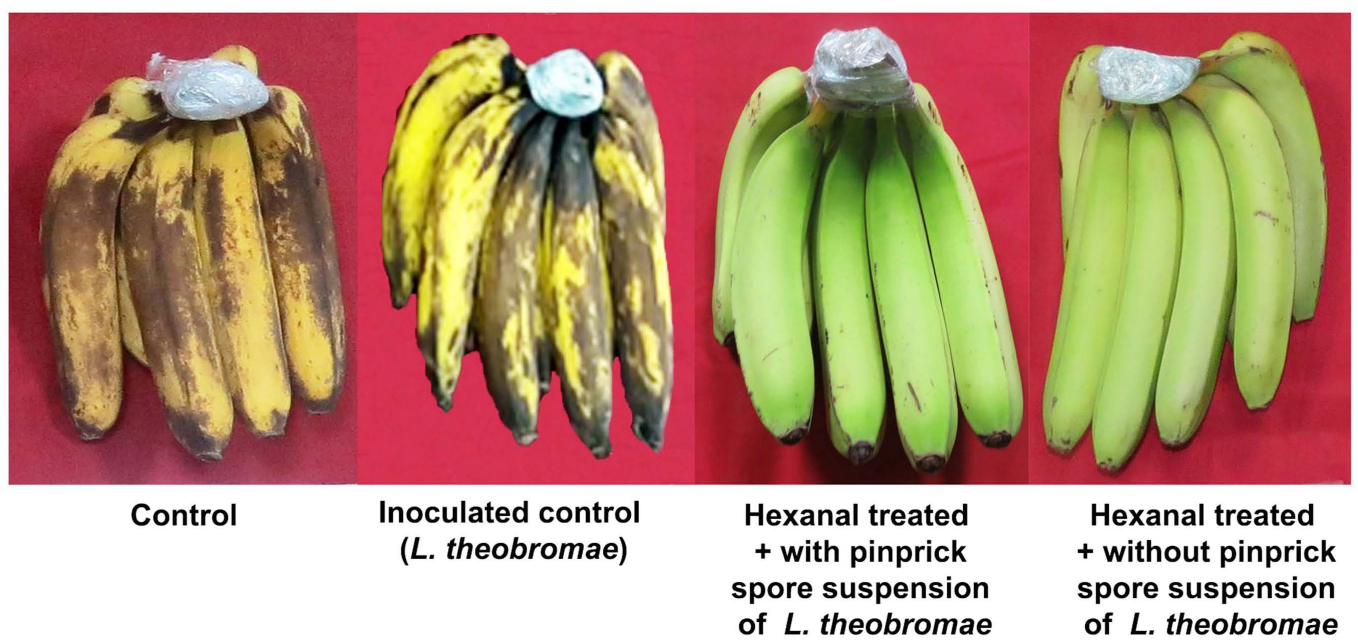

B

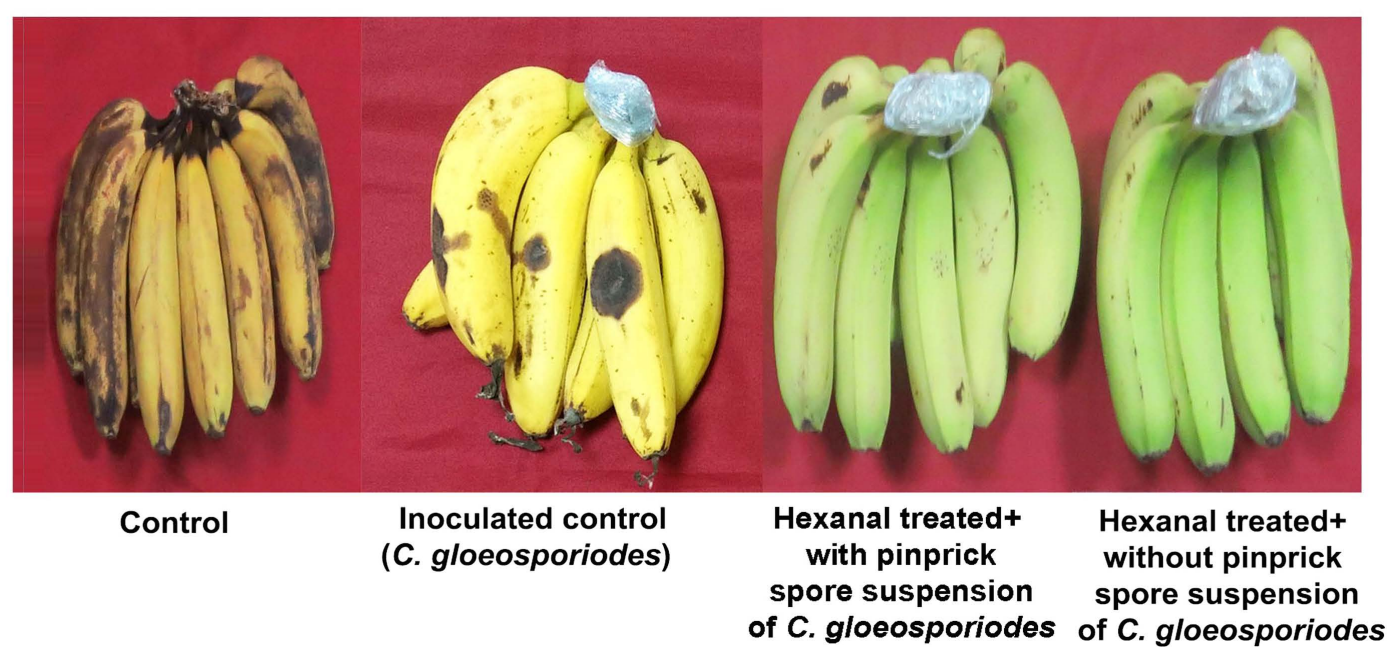

Fig. 5. In vivo experiments on banana fruits inoculated with spore suspension of respective pathogens Lasiodiplodia theobromae (A) and Colletotrichum gloeosporioides (B), with or without exposure to hexanal vapor $800 \mathrm{ppm}$ for $3 \mathrm{~h}$. The images were recorded 14 days after the treatment at room temperature.

tissue) at the 6th day of treatment and decreased gradually thereafter (Fig. 8A and B, Supplementary Tables 3 and 7). Similarly, PAL activity also increased due to hexanal till 9th day $(6.12 ; 6.342 \mathrm{nmol}$ of trans-cinnamic acid/min/g of fresh tissue respectively), compared to control $(2.23 \mathrm{nmol}$ of trans-cinnamic acid $/ \mathrm{min} / \mathrm{g}$ of fresh tissue). PAL declined thereafter regardless of treatments (Fig. 8C and D). The $\beta$-1,3-glucanase also increased when exposed to hexanal vapor at $800 \mathrm{ppm}$ till 9 days (212 and $201 \mu \mathrm{g}$ of glucose/ $\mathrm{min} / \mathrm{g}$ of fresh tissue) in comparison to control $(68 \mu \mathrm{g}$ of glucose/min/g of fresh tissue) and then decreased thereafter (Fig. 8E and F). Together these data indicate that hexanal induces significant biochemical changes in banana that are associated with shelf life and defense against postharvest fungal pathogens.
Changes in the phenolic content of banana fruit. Accumulation of phenolics was observed in pre-inoculated banana fruit treated with hexanal vapor $(800 \mathrm{ppm})$ and registered the highest value on the 9th day after treatment. The hexanal vapor treated banana fruit pre-inoculated with L. theobromae and C. gloeosporioides recorded higher phenolics (595.2 and 587.1 catechol equivalents/g of fresh tissue) than control (249.3 and 239.3 catechol equivalents/ $\mathrm{g}$ of fresh tissue). The control fruit had increased phenolics up to 6 days after treatment and declined thereafter (Fig. $9 \mathrm{~A}$ and $\mathrm{B})$.

Changes in the PLD activity. The activity of PLD in hexanal vapor treated fruits was lower than control during the entire period of observations ( 0 to 12 days). The PLD activities were lower in hexanal vapor treated fruit regard- 

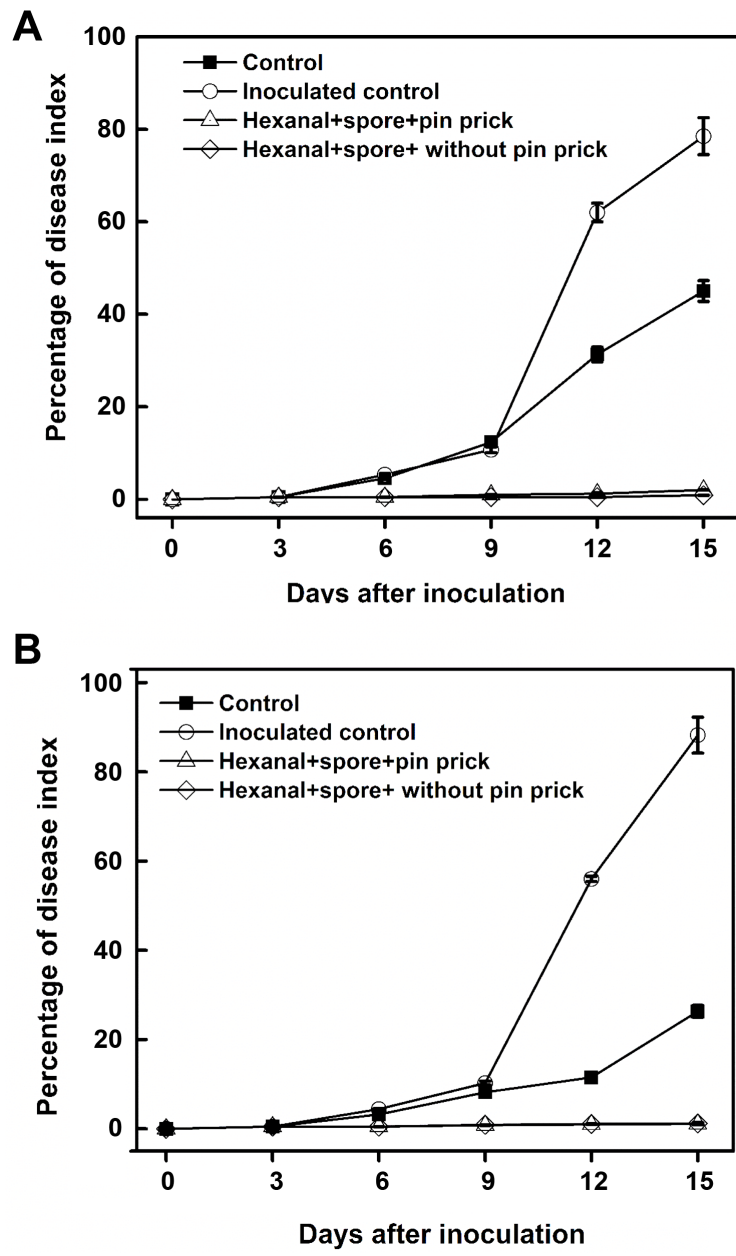

Fig. 6. Disease index of Lasiodiplodia theobromae (A) and Colletotrichum gloeosporioides (B) pathogens on banana fruit rot. The data represent the means of 3-4 replicates \pm SE.

less of inoculation with either pathogen (Fig. 9C and D).

High-resolution imaging. The high-resolution images of SEM exhibited colonization and penetration of L. theobromae and $C$. gloeosporioides on the surface of the control fruit. On the other hand, hexanal vapor exposed fruit had shown to have lignifications on the surface of the fruit and no colonization was observed on the 9th day of treatment (Fig. 10A-F).

\section{Discussion}

Infection by postharvest pathogens may occur before harvest, during the growing season or after harvest, or during the handling and transport. Once the pathogens invaded the tissues, it is hardly possible to prevent the spread of the disease as the fruits start to ripen and will be consumed within
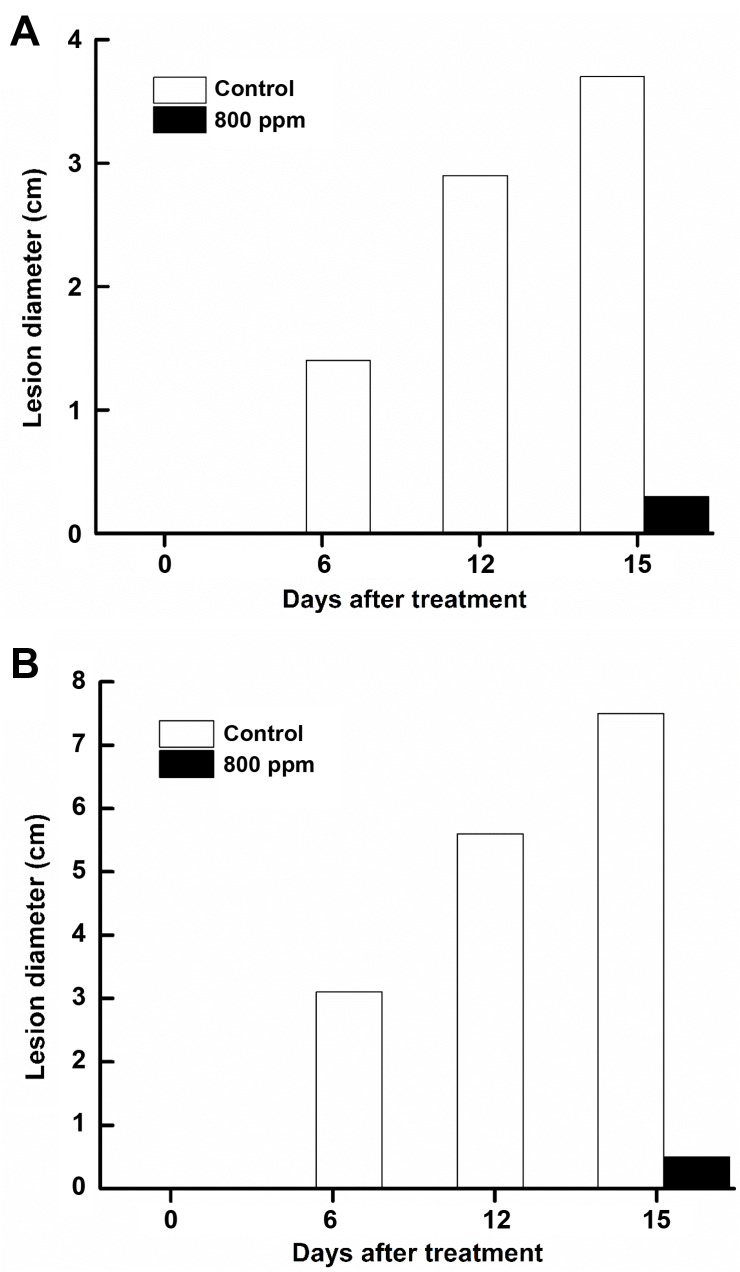

Fig. 7. Effect of hexanal vapor (800 ppm) on banana lesion development, Lasiodiplodia theobromae (A) and Colletotrichum gloeosporioides (B) pathogens. The data represent the means of 3-4 replicates $\pm \mathrm{SE}$.

a short time after. In many cases, the postharvest diseases are rarely recognized with obvious symptoms during the growing season, as the pathogen remain latent during this phase. Hence controlling latent infections in the postharvest environment of fruits is very important (Caruso and Ramsdell, 1995). Since anthracnose and stem-end rot cause extensive damage during postharvest, any preventive treatment has to be integrated well before the pathogens start infecting the fruit tissues.

At present fungicides are used at postharvest to control such infections (Stoytcheva, 2011) and there is an immediate need to find alternative solutions. Some of the natural volatile compounds such as cinnamaldehyde and benzaldehyde significantly inhibited the mycelial growth and reduced disease incidence of some postharvest diseases such as stem-end rot, anthracnose, gray mold and brown rot of 

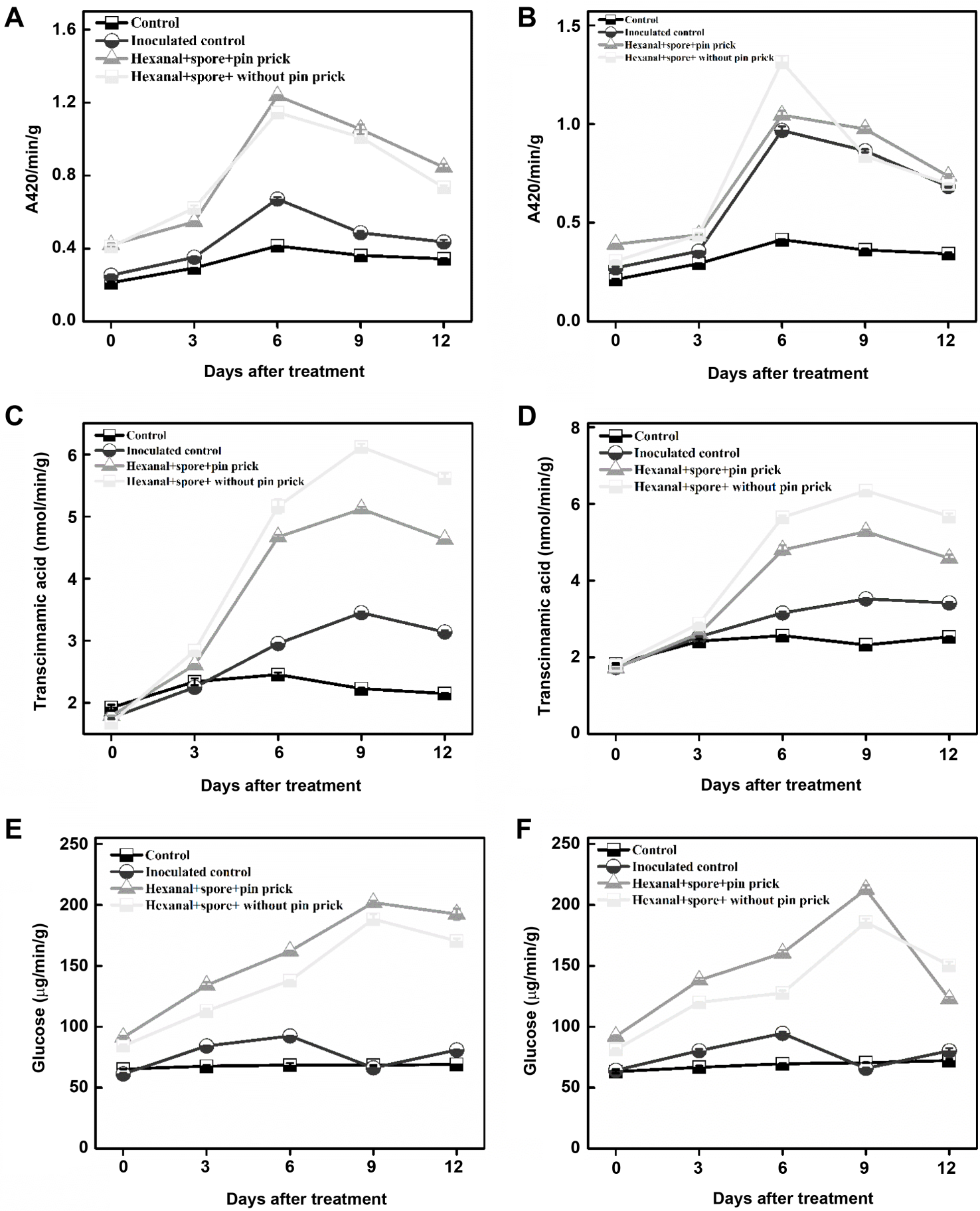

Fig. 8. Changes in defense enzyme activity in hexanal exposed Lasiodiplodia theobromae and Colletotrichum gloeosporioides inoculated banana tissues. (A, B) Peroxidase activity. (C, D) Phenylalanine ammonia-lyase activity. (E, F) Glucanase activity. The data represent the means of 3-4 replicates \pm SE.

fruits during postharvest storage (Sivakumar et al., 2001; Wilson et al., 1987). Hexanal can be used as another volatile to control the proliferation of postharvest pathogens. The exposure to hexanal vapor causes the hyphal cell wall membrane disruption (Fallik et al., 1998) and distortion of cell wall components, plasma membrane in conidia (Arroyo et al., 2007). In addition, it has been shown that the hexanal vapor reduced $94 \%$ of spore viability in Penicillium expansum (Fan et al., 2006).

In this study, we have shown sufficient evidence that 
A

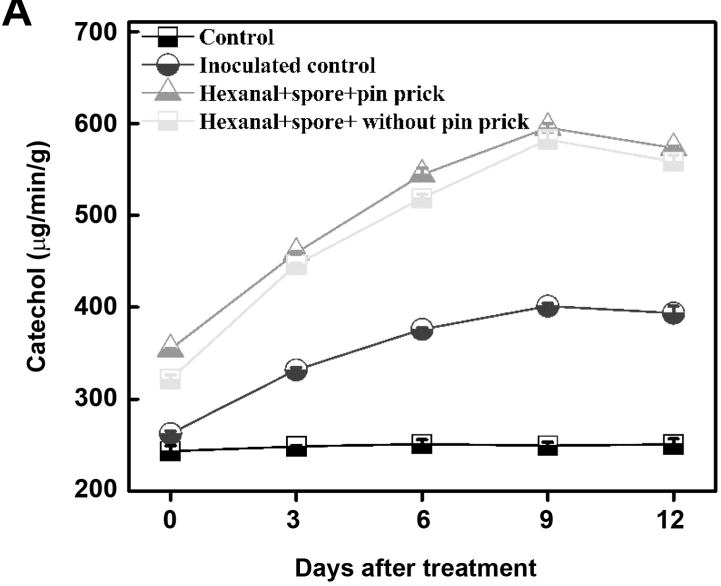

C

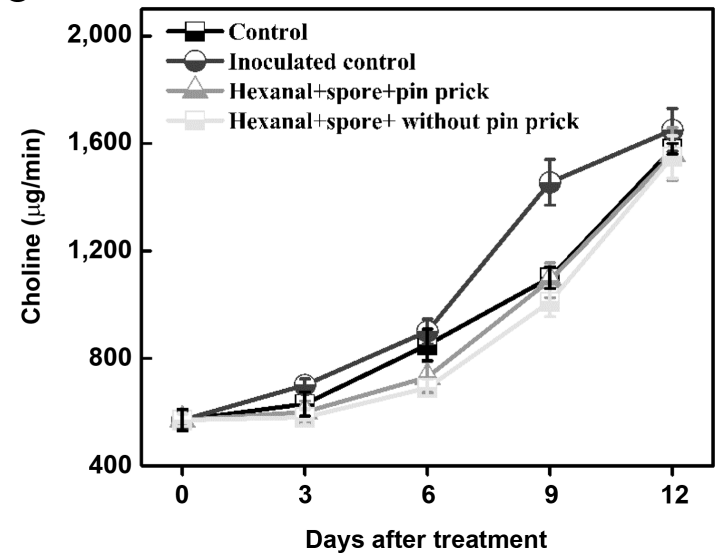

B

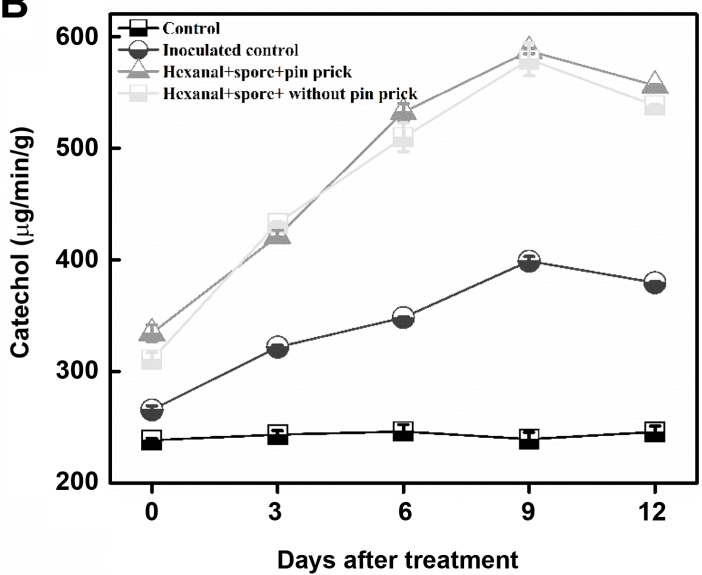

D

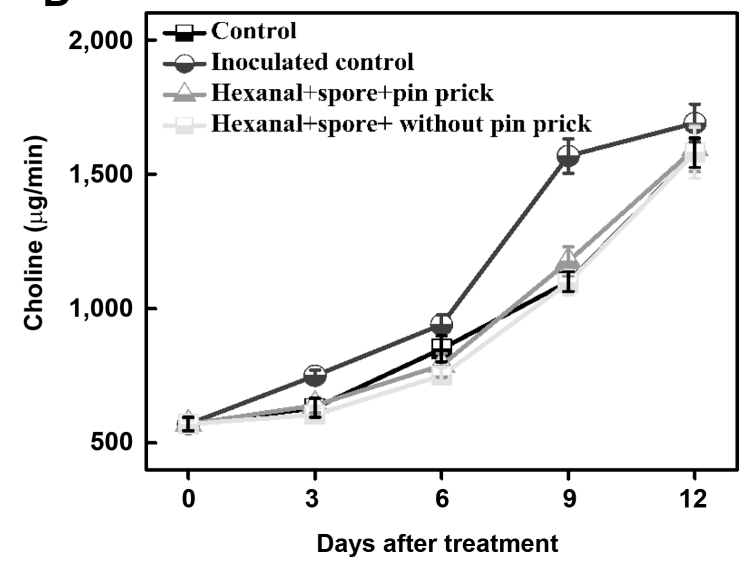

Fig. 9. Changes in phenol activity (A, B) and phospholipase D activity (C, D) in hexanal exposed Lasiodiplodia theobromae and Colletotrichum gloeosporioides inoculated banana tissues. The data represent the means of 3-4 replicates \pm SE.

hexanal can be an effective treatment to control the postharvest pathogens and to extend the shelf life of banana fruits during storage. Treating banana fruits with $800 \mathrm{ppm}$ of hexanal had increased the postharvest shelf life to 15 days (Figs. 5 and 6). Such an extension is most likely due to the inhibition of spore germination and mycelial growth of these fungi by hexanal exposure for just $3 \mathrm{~h}$ (Figs. 3 and 4). Hexanal has been shown to have similar inhibitory effect on other postharvest pathogens such as $B$. cinerea and M. fructicola (Song et al., 2007). Recently, Seethapathy et al. (2016) have shown that the hexanal treated mango fruit volatile profiles were uniquely different in terms of additional compounds detected that are known to have fungistatic effects. Perhaps hexanal may have such an indirect effect by stimulating the release of such fungistatic volatiles from banana as well. However, this needs to be explored further to draw any conclusions

Appearance of disease incidence in later stages of ripening in the surface-sterilized control is likely due to latent pathogens that become virulent during ripening. It should be noted that the scoring was based only on true disease symptoms rather than normal discoloration which generally appears in the banana. Earlier studies have shown that hexanal vapor treatment in peach fruits inhibited the fungal growth such as C. gloeosporioides (Song et al., 2007), M. fructicola, and M. laxa in peaches (Baggio et al., 2014) and mold such as Penicillium expansum in pear fruits (Neri et al., 2006). Apples exposed to $900 \mu \mathrm{l} / 1$ hexanal vapor for $48 \mathrm{~h}$ showed signs of phytotoxicity, expressed as surface browning (Fan et al., 2006). This could be a much higher dose and longer duration as our studies indicate it to be effective $5.02 \mu \mathrm{l} / 1$ for $3 \mathrm{~h}$ without any phytotoxicity symptoms. These results suggest that hexanal is quite effective at low dose that can be adopted for commercial level postharvest treatment.

In plants, the defense enzymes such as PO, PAL, glucanase, and chitinase are induced as a first line of defense against pathogen infection (Anand et al., 2007; Barber 
A

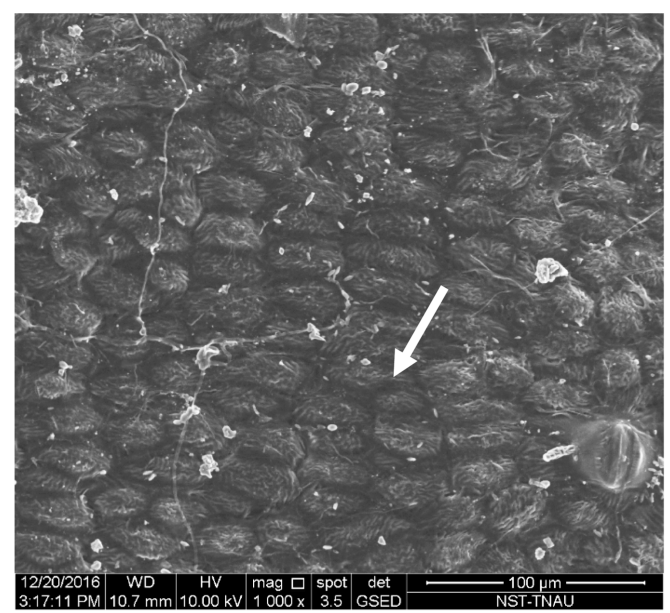

Healthy

C

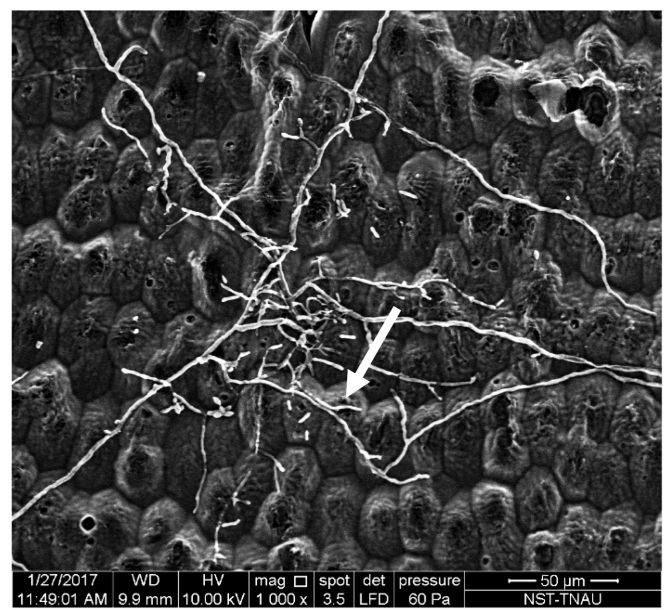

L. theobromae inoculated

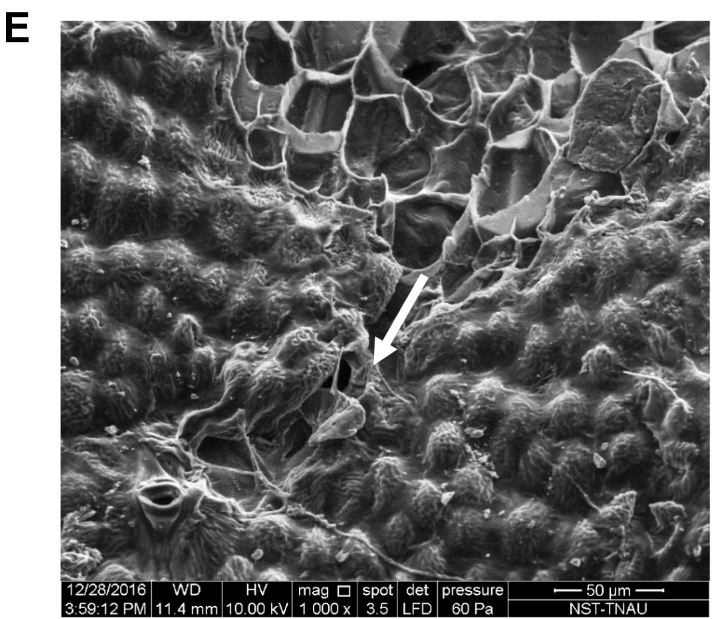

Hexanal vapor (800 ppm treated) +

L. theobromae inoculated
B

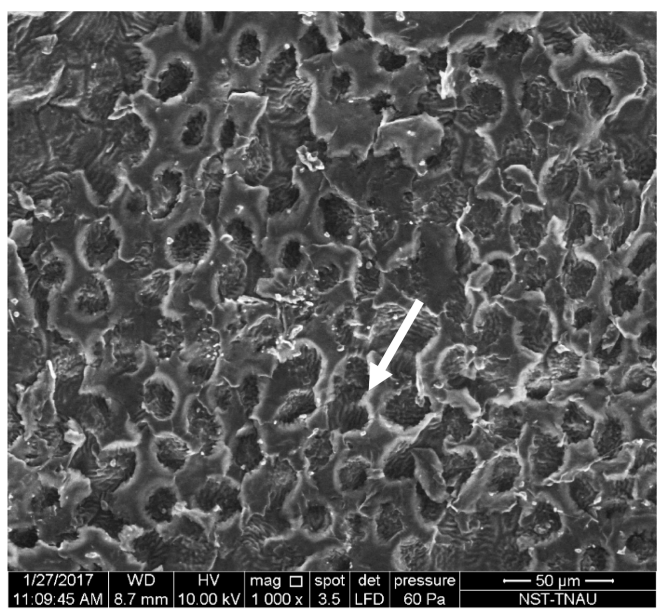

Hexanal vapor (800 ppm) treated

D

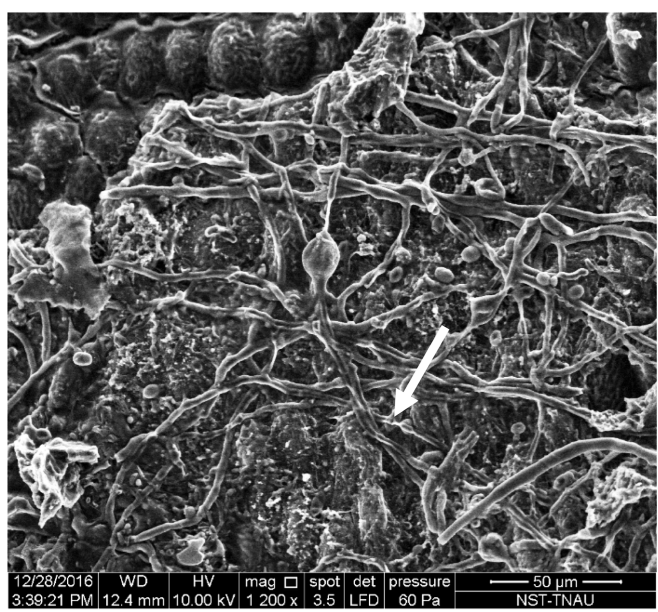

C. gloeosporioides inoculated

$\mathbf{F}$

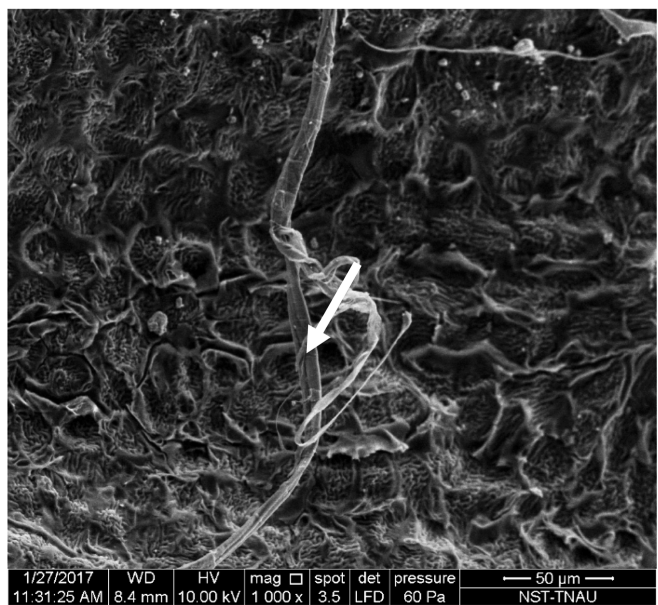

Hexanal vapor (800 ppm treated) +

C. gloeosporioides inoculated

Fig. 10. Changes in the banana fruit peel on 7 DAT (A-F). (A) Untreated banana. (B) Vapor treated (800 ppm). (C, D) Inoculated control showed colonization of hyphae and appressoria formation. (E, F) Hexanal vapor treated banana tissues upon challenge inoculated with the pathogen showed lignification and distorted hyphae. The experiment was repeated twice with two different biological samples and similar results were obtained. L. theobromae, Lasiodiplodia theobromae; C. gloeosporioides, Colletotrichum gloeosporioides. 
and Mitchell, 1997; Dixon et al., 1995). PO, a key enzyme involved in various defense-related processes includes cross-linking of phenolics-glycoproteins, polysaccharidesmonomers, and hypersensitive response (Thakker et al., 2013). In addition, the deposition of phenolic materials on the cell membranes acts as a barrier for the development of the pathogen (Agrios, 2005; Thakker et al., 2013). Phenolic compounds enhance the mechanical strength of plant cell walls and also act as defense molecules against pathogen infection (Ganeshamoorthi et al., 2008; M'Piga et al., 1997). Increased PAL levels were observed during pathogen infection, other biotic and abiotic stresses (Lafuente et al., 2003). $\beta$-1,3-glucanase is primarily involved in the cell wall modifications tailored towards microbial defense (Beffa et al., 1996; Smart, 1991). In general, $\beta$-1,3glucanase enzymes degrade both plant and pathogen cell wall and derivatives arose from cell wall degradation act as elicitors in defense response (Bowles, 1990). Hexanal induced elevation in $\beta$-1,3-glucanase, PAL, PO, and phenolic activity in treated banana fruits could be the reason for the increased resistance against pathogens.

Fruit softening during the ripening process is associated with loss of membrane integrity attributed by families of enzymes including cellulase, glucanase, polygalacturonase, and phospholipases (Payasi et al., 2009). PLD is a key enzyme involved in the hydrolysis of phospholipids, which are the primary backbones of the cellular membrane and increased PLD activity is observed during fruit ripening in various crops (Paliyath and Droillard, 1992; Yuan et al., 2005). Hexanal inhibits the PLD enzyme thereby increasing the shelf life of fruits. Our result shows that the PLD levels increased during ripening as well as due to fungal inoculation in the control fruits, while, hexanal lowers the PLD up to the 9th day of storage (Fig. 9). This results in the extension of shelf life. This clearly shows that the membrane integrity was maintained until 9th day by inhibiting PLD in the treated fruits which likely inhibited fungal growth due to hexanal treatment. Recently it was shown that hexanal based nanoformulation treated banana fruits exhibited extra firmness, shininess, increased total soluble solids, sugar levels indicating improved quality during storage (Venkatachalam et al., 2018) as observed in the current study.

The primary mechanism of action of hexanal on $C$. gloeosporioides and $L$. theobromae is not fully understood. Based on our evidence it is possible that keeping the membrane intact as a result of hexanal treatment may have contributed to a type of physical resistance (confirmed by SEM), coupled with elevated levels of defense molecules described previously, contributing to biochemical resistance. Thus the cumulative effects render the hexanal treated fruits with an extended shelf life and thus contributing to lessen postharvest waste.

The high level of disease control achieved when naturally infected banana fruit treated with hexanal, suggests that it can penetrate tissues to a certain extent. It has been shown that the whole apples inoculated with $P$. expansum at $22^{\circ} \mathrm{C}$ and $4^{\circ} \mathrm{C}$ exposed to hexanal vapor reduced the decay (Fan et al., 2006), indicating that it could be applied commercially at low temperature. Although we did not test temperature effects in the present study, it is possible to increase hexanal vapor concentration at lower temperatures by using heat-vaporization. The volatile nature of hexanal and its potential ability to penetrate stacked commodities would be an added advantage to expose the fruits during transport and storage. The potential use of hexanal as a tool for postharvest shelf-life extension is promising from our current studies, although large scale studies might be needed to figure out the economics more accurately. The fact that hexanal vapor is as effective as a liquid opens up its use for extending shelf life in other soft fruits where using a liquid form of protection is not preferred. Further using such external products as a vapor also limits its exposure to the fruits as well as environment thus making it ecofriendlier.

Hexanal is a natural volatile and had significant inhibitory effects on postharvest pathogens and it can be easily incorporated into supply chain management (Supplementary Tables 1-8). Treatment with hexanal vapor at $5.02 \mu 1 / 1$ for $3 \mathrm{~h}$ substantially reduced the infection and decay of banana fruit. The use of hexanal as an antimicrobial fumigant is a promising alternative for chemical treatments.

\section{Acknowledgments}

S.S would like to acknowledge DST-SERB, GOI for providing him with the National Post-Doctoral Fellowship (NPDF) as support of his studies.

\section{Electronic Supplementary Material}

Supplementary materials are available at The Plant Pathology Journal website (http://www.ppjonline.org/).

\section{References}

Abayasekara, C. L., Adikaram, N. K. B., Wanigasekara, U. W. N. P. and Bandara, B. M. R. 2013. Phyllosticta musarum infection-induced defences suppress anthracnose disease caused by Colletotrichum musae in banana fruit cv 'Embul'. Plant 
Pathol. J. 29:77-86.

Agrios, G. N. 2005. Plant pathology. 5th ed. Elsevier Academic Press, Burlington, MA, USA. 922 pp.

Alkarkhi, A. F. M., Ramli, S. B., Yong, Y. S. and Easa, A. M. 2011. Comparing physicochemical properties of banana pulp and peel flours prepared from green and ripe fruits. Food Chem. 129:312-318.

Anand, T., Chandrasekaran, A., Kuttalam, S., Raguchander, T., Prakasam, V. and Samiyappan, R. 2007. Association of some plant defense enzyme activities with systemic resistance to early leaf blight and leaf spot induced in tomato plants by azoxystrobin and Pseudomonas fluorescens. J. Plant Interact. 2:233-244.

Anusuya, P., Nagaraj, R., Janavi, G. J., Subramanian, K. S., Paliyath, G. and Subramanian, J. 2016. Pre-harvest sprays of hexanal formulation for extending retention and shelf-life of mango (Mangifera indica L.) fruits. Sci. Hortic. 211:231-240.

Arroyo, F. T., Moreno, J., Daza, P., Boianova, L. and Romero, F. 2007. Antifungal activity of strawberry fruit volatile compounds against Colletotrichum acutatum. J. Agric. Food Chem. 55:5701-5707.

Baez-Sañudo, M., Siller-Cepeda, J., Muy-Rangel, D. and Heredia, J. B. 2009. Extending the shelf-life of bananas with 1-methylcyclopropene and a chitosan-based edible coating. $J$. Sci. Food Agric. 89:2343-2349.

Baggio, J. S., Lourenço, S. D. A. and Amorim, L. 2014. Eradicant and curative treatments of hexanal against peach brown rot. Sci. Agric. 71:72-76.

Bailly, A., Groenhagen, U., Schulz, S., Geisler, M., Eberl, L. and Weisskopf, L. 2014. The inter-kingdom volatile signal indole promotes root development by interfering with auxin signalling. Plant J. 80:758-771.

Baldwin, I. T., Halitschke, R., Paschold, A., von Dahl, C. C. and Preston, C. A. 2006. Volatile signaling in plant-plant interactions: "talking trees" in the genomics era. Science 311:812815.

Barber, M. S. and Mitchell, H. J. 1997. Regulation of phenylpropanoid metabolism in relation to lignin biosynthesis in plants. Int. Rev. Cytol. 172:243-293.

Beffa, R. S., Hofer, R.-M., Thomas, M. and Meins, F. Jr. 1996. Decreased susceptibility to viral disease of $\beta$-1,3-glucanasedeficient plants generated by antisense transformation. Plant Cell. 8:1001-1011.

Boudhrioua, N., Giampaoli, P. and Bonazzi, C. 2003. Changes in aromatic components of banana during ripening and airdrying. LWT Food Sci. Technol. 36:633-642.

Bowles, D. J. 1990. Defense-related proteins in higher plants. Annu. Rev. Biochem. 59:873-907.

Caruso, F. L. and Ramsdell, D. C. 1995. Compendium of blueberry and cranberry diseases. American Phytopathological Society, St. Paul, MN, USA. 87 pp.

Dickerson, D. P., Pascholati, S. F., Hagerman, A. E., Butler, L. G. and Nicholson, R. L. 1984. Phenylalanine ammonia-lyase and hydroxycinnamate: CoA ligase in maize mesocotyls inocu- lated with Helminthosporium maydis or Helminthosporium carbonum. Physiol. Plant Pathol. 25:111-123.

Dixon, R. A., Paiva, N. L. and Bhattacharyya, M. K. 1995. Engineering disease resistance in plants: an overview. In: Molecular methods in plant pathology, eds. by R. P. Singh and U. S. Singh, pp. 249-270. CRC Press, Boca Raton, FL, USA.

Dobson, H. E. M. 2006. Relationship between floral fragrance composition and type of pollinator. In: Biology of floral scent, eds. by N. Dudareva and E. Pichersky, pp. 147-198. CRC Press, Boca Raton, FL, USA.

El Kayal, W., El-Sharkawy, I., Dowling, C., Paliyath, G., Sullivan, J. A. and Subramanian, J. 2017a. Effect of preharvest application of hexanal and growth regulators in enhancing shelf life and regulation of membrane-associated genes in strawberry. Can. J. Plant Sci. 97:1109-1120.

El Kayal, W., Paliyath, G., Sullivan, J. A. and Subramanian, J. 2017b. Phospholipase D inhibition by hexanal is associated with calcium signal transduction events in raspberry. Hortic. Res. 4:17042.

Fallik, E., Archbold, D. D., Hamilton-Kemp, T. R., Clements, A. M., Collins, R. W. and Barth, M. M. 1998. (E)-2-hexenal can stimulate Botrytis cinerea growth in vitro and on strawberries in vivo during storage. J. Am. Soc. Hortic. Sci. 123:875-881.

Fan, L., Song, J., Beaudry, R. M. and Hildebrand, P. D. 2006. Effect of hexanal vapor on spore viability of Penicillium expansum, lesion development on whole apples and fruit volatile biosynthesis. J. Food Sci. 71:M105-M109.

Ganeshamoorthi, P., Anand, T., Prakasam, V., Bharani, M., Ragupathi, N. and Samiyappan, R. 2008. Plant growth promoting rhizobacterial (PGPR) bioconsortia mediates induction of defense-related proteins against infection of root rot pathogen in mulberry plants. J. Plant Interact. 3:233-244.

Gill, P. P. S., Jawandha, S. K., Kaur, N., Singh, N. and Sangwan, A. 2015. Influence of LDPE packaging on post harvest quality of mango fruits during low temperature storage. Bioscan 10:1177-1180.

Hammerschmidt, R., Nuckles, E. M. and Kuć, J. 1982. Association of enhanced peroxidase activity with induced systemic resistance of cucumber to Colletotrichum lagenarium. Physiol. Plant Pathol. 20:73-82.

Heil, M. and Silva Bueno, J. C. 2007. Within-plant signaling by volatiles leads to induction and priming of an indirect plant defense in nature. Proc. Natl. Acad. Sci. U. S. A. 104:54675472.

Jincy, M., Djanaguiraman, M., Jeyakumar, P., Subramanian, K. S., Jayasankar, S. and Paliyath, G. 2017. Inhibition of phospholipase D enzyme activity through hexanal leads to delayed mango (Mangifera indica L.) fruit ripening through changes in oxidants and antioxidant enzymes activity. Sci. Hortic. 218:316-325.

Johnston, P. R. and Jones, D. 1997. Relationships among Colletotrichum isolates from fruit-rots assessed using rDNA sequences. Mycologia 89:420-430.

Kanazawa, K. and Sakakibara, H. 2000. High content of dopa- 
mine, a strong antioxidant, in Cavendish banana. J. Agric. Food Chem. 48:844-848.

Kasso, M. and Bekele, A. 2018. Post-harvest loss and quality deterioration of horticultural crops in Dire Dawa Region, Ethiopia. J. Saudi Soc. Agric. Sci. 17:88-96.

Khan, S. H., Aked, J. and Magan, N. 2001. Control of the anthracnose pathogen of banana (Colletotrichum musae) using antioxidants alone and in combination with thiabendazole or imazalil. Plant Pathol. 50:601-608.

Kumar, S. K., El Kayal, W., Sullivan, J. A., Paliyath, G. and Jayasankar, S. 2018. Pre-harvest application of hexanal formulation enhances shelf life and quality of 'Fantasia' nectarines by regulating membrane and cell wall catabolismassociated genes. Sci. Hortic. 229:117-124.

Lafuente, M. T., Zacarias, L., Martínez-Téllez, M. A., SanchezBallesta, M. T. and Granell, A. 2003. Phenylalanine ammonia-lyase and ethylene in relation to chilling injury as affected by fruit age in citrus. Postharvest Biol. Technol. 29:308-317.

Lanciotti, R., Belletti, N., Patrignani, F., Gianotti, A., Gardini, F. and Guerzoni, M. E. 2003. Application of hexanal, E-2-hexenal, and hexyl acetate to improve the safety of fresh-sliced apples. J. Agric. Food Chem. 51:2958-2963.

Liu, H., Qiu, N., Ding, H. and Yao, R. 2008. Polyphenols contents and antioxidant capacity of 68 Chinese herbals suitable for medical or food uses. Food Res. Int. 41:363-370.

Liu, S.-C., Lin, J.-T., Wang, C.-K., Chen, H.-Y. and Yang, D.J. 2009. Antioxidant properties of various solvent extracts from lychee (Litchi chinenesis Sonn.) flowers. Food Chem. 114:577-581.

López-Fernández, O., Rial-Otero, R., González-Barreiro, C. and Simal-Gándara, J. 2012. Surveillance of fungicidal dithiocarbamate residues in fruits and vegetables. Food Chem. 134:366-374.

Ministry of Agriculture. 2015. Post harvest profile of banana: 2015. Government of India, Ministry of Agriculture, Department of Agriculture \& Cooperation, Directorate of Marketing \& Inspection, Nagpur, India. 87 pp.

Ministry of Agriculture \& Farmers' Welfare. 2018. Horticultural statistics at a glance 2018. Government of India, Ministry of Agriculture \& Farmers' Welfare, Department of Agriculture, Cooperation \& Farmers' Welfare, Horticulture Statistics Division, New Delhi, India. 458 pp.

Mohan, C., Sridharan, S., Subramanian, K. S., Natarajan, N. and Nakkeeran, S. 2017. Effect of nanoemulsion of hexanal on honey bees (Hymenoptera; Apidae). J. Entomol. Zool. Stud. 5:1415-1418.

Mohapatra, D., Mishra, S. and Sutar, N. 2010. Banana and its byproduct utilisation: an overview. J. Sci. Ind. Res. 69:323-329.

M'Piga, P., Bélanger, R. R., Paulitz, T. C. and Benhamou, N. 1997. Increased resistance to Fusarium oxysporum f. sp. radicis-lycopersici in tomato plants treated with the endophytic bacterium Pseudomonas fluorescens strain 63-28. Physiol. Mol. Plant Pathol. 50:301-320.

Myung, K., Hamilton-Kemp, T. R. and Archbold, D. D. 2007. In- teraction with and effects on the profile of proteins of Botrytis cinerea by C6 aldehydes. J. Agric. Food Chem. 55:21822188.

Neri, F., Mari, M. and Brigati, S. 2006. Control of Penicillium expansum by plant volatile compounds. Plant Pathol. 55:100105.

Paliyath, G. and Droillard, M. J. 1992. The mechanisms of membrane deterioration and disassembly during senescence. Plant Physiol. Biochem. 30:789-812.

Pan, Q., Te, Y. S. and Kuc, J. 1991. A technique for detection of chitinase, $\beta$-1,3-glucanase, and protein patterns after single separation using polyacrylamide gel electrophoresis or isoelectricfocusing. Phytopathology 81:970-974.

Payasi, A., Mishra, N. N., Chaves, A. L. S. and Singh, R. 2009. Biochemistry of fruit softening: an overview. Physiol. Mol. Biol. Plants 15:103-113.

Prabakar, K., Raguchander, T., Parthiban, V. K., Muthulakshmi, P. and Prakasam, V. 2005. Post harvest fungal spoilage in mango at different levels marketing. Madras Agric. J. 92:4248.

Rangaswami, G. and Mahadevan, A. 1999. Diseases of crop plants in India. 4th ed. Prentice-Hall of India Pvt. Ltd., New Delhi, India. 548 pp.

Ryu, C.-M., Farag, M. A., Hu, C.-H., Reddy, M. S., Kloepper, J. W. and Paré, P. W. 2004. Bacterial volatiles induce systemic resistance in Arabidopsis. Plant Physiol. 134:1017-1026.

Sangeetha, G., Anandan, A. and Rani, S. U. 2012. Morphological and molecular characterisation of Lasiodiplodia theobromae from various banana cultivars causing crown rot disease in fruits. Arch. Phytopathol. Plant Prot. 45:475-486.

Seethapathy, P., Gurudevan, T., Subramanian, K. S. and Kuppusamy, P. 2016. Bacterial antagonists and hexanal-induced systemic resistance of mango fruits against Lasiodiplodia theobromae causing stem-end rot. J. Plant Interact. 11:158166.

Sharifi, R. and Ryu, C. M. 2018. Sniffing bacterial volatile compounds for healthier plants. Curr. Opin. Plant Biol. 44:88-97.

Sharma, M., Jacob, J. K., Subramanian, J. and Paliyath, G. 2010. Hexanal and 1-MCP treatments for enhancing the shelf life and quality of sweet cherry (Prunus avium L.). Sci. Hortic. 125:239-247.

Sholberg, P. 2009. Control of postharvest decay by fumigation with acetic acid or plant volatile compounds. Fresh Produce 3(Spec 1):80-86.

Sholberg, P. and Randall, P. 2005. Hexanal vapor for postharvest decay control and aroma production in stored pome fruit. Phytopathology 95:S96.

Sholberg, P. L. and Randall, P. 2007. Fumigation of stored pome fruit with hexanal reduces blue and gray mold decay. HortScience 42:611-616.

Sivakumar, D., Wijeratnam, R. S. W., Marikar, F. M. M. T., Abeyesekere, M. and Wijesundera, R. L. C. 2001. Antagonistic effect of Trichoderma harzianum on post harvest pathogens of rambutans. Acta Hortic. 553:389-392. 
Smart, M. G. 1991. The plant cell wall as a barrier to fungal invasion. In: The fungal spore and disease initiation in plants and animals, eds. by G. T. Cole and H. C. Hoch, pp. 47-66. Springer-Verlag, Boston, MA, USA.

Song, J., Fan, L., Forney, C., Campbell-Palmer, L. and Fillmore, S. 2010. Effect of hexanal vapor to control postharvest decay and extend shelf-life of highbush blueberry fruit during controlled atmosphere storage. Can. J. Plant Sci. 90:359-366.

Song, J., Hildebrand, P. D., Fan, L., Forney, C. F., Renderos, W. E., Campbell-Palmer, L. and Doucette, C. 2007. Effect of hexanal vapor on the growth of postharvest pathogens and fruit decay. J. Food Sci. 72:M108-M112.

Song, J., Leepipattanawit, R., Deng, W. and Beaudry, R. M. 1996. Hexanal vapor is a natural, metabolizable fungicide: inhibition of fungal activity and enhancement of aroma biosynthesis in apple slices. J. Am. Soc. Hortic. Sci. 121:937-942.

Stoytcheva, M. 2011. Pesticides in the modern world: trends in pesticides analysis. InTech, Rijeka, Croatia. 514 pp.

Thakker, J. N., Patel, S. and Dhandhukia, P. C. 2013. Induction of defense-related enzymes in banana plants: effect of live and dead pathogenic strain of Fusarium oxysporum f. sp. cubense. ISRN Biotechnol. 2013:601303.

Thavong, P., Archbold, D. D., Pankasemsuk, T. and Koslanund, R. 2011. Hexanal vapours suppress spore germination, mycelial growth, and fungal-derived cell wall degrading enzymes of postharvest pathogens of longan fruit. Chiang Mai J. Sci. 38:139-150.

Tiwari, K. and Paliyath, G. 2011. Microarray analysis of ripeningregulated gene expression and its modulation by 1-MCP and hexanal. Plant Physiol. Biochem. 49:329-340.

Utto, W., Mawson, J. A. and Bronlund, J. E. 2008. Hexanal reduces infection of tomatoes by Botrytis cinerea whilst maintaining quality. Postharvest Biol. Technol. 47:434-437.

Venkatachalam, K., Muthuvel, I., Sundaresan, S., Subramanian, K. S., Janaki, J. G., Sullivan, J. A., Paliyath, G. and Subramanian, J. 2018. Post-harvest dip of enhanced freshness formulation to extend the shelf life of banana (Musa acuminata cv. Grand Naine) in India. Trop. Agric. 95:1-13.

Wang, Y., Tang, M., Hao, P., Yang, Z., Zhu, L. and He, G. 2008. Penetration into rice tissues by brown planthopper and fine structure of the salivary sheaths. Entomol. Exp. Appl. 129:295-307.

Wilson, C. L., Franklin, J. D. and Otto, B. E. 1987. Fruit volatiles inhibitory to Monilinia fructicola and Botrytis cinerea. Plant Dis. 71:316-319.

Yuan, H., Chen, L., Paliyath, G., Sullivan, A. and Murr, D. P. 2005. Characterization of microsomal and mitochondrial phospholipase D activities and cloning of a phospholipase D alpha cDNA from strawberry fruits. Plant Physiol. Biochem. 43:535-547. 